\title{
Efficacy of Precocene I from Desmosstachya bipinnata as an Effective Bioactive Molecules against the Spodoptera litura Fab. and Its Impact on Eisenia fetida Savigny
}

\author{
Narayanan Shyam Sundar ${ }^{1}$, Sengodan Karthi ${ }^{1}$, Haridoss Sivanesh ${ }^{1}$, Vethamonickam Stanley-Raja ${ }^{1}$, \\ Kanagaraj Muthu-Pandian Chanthini ${ }^{1}$, Ramakrishnan Ramasubramanian ${ }^{1}$, Govindaraju Ramkumar ${ }^{1}$, \\ Athirstam Ponsankar ${ }^{2}$, Kilapavoor Raman Narayanan ${ }^{3}$, Prabhakaran Vasantha-Srinivasan ${ }^{4}$ (D), \\ Jawaher Alkahtani ${ }^{5}$, Mona S. Alwahibi ${ }^{5}$, Wayne Brian Hunter ${ }^{6}\left(\mathbb{D}\right.$, Sengottayan Senthil-Nathan ${ }^{1, *(\mathbb{D})}$, \\ Krutmuang Patcharin ${ }^{7,8} \mathbb{D}^{\mathbb{D}}$, Ahmed Abdel-Megeed ${ }^{9, *}$, Rady Shawer ${ }^{9}$ iD and Aml Ghaith 10
}

1 Division of Biopesticides and Environmental Toxicology, Sri Paramakalyani Centre for Excellence in Environmental Sciences, Manonmaniam Sundaranar University, Alwarkurichi 627 412, India; krn.shyamsundar@gmail.com (N.S.S.); karthientomology@gmail.com (S.K.); sivanesh2020@gmail.com (H.S.); stanleyrajamsu@gmail.com (V.S.-R.); clairdelune127@gmail.com (K.M.-P.C.); heyram.8238@gmail.com (R.R.); ayvidram@gmail.com (G.R.)

2 Department of Biotechnology, Sri Paramakalyani College, Alwarkurichi 627 412, India; sreeram.pons@gmail.com

check for updates

Citation: Sundar, N.S.; Karthi, S.; Sivanesh, H.; Stanley-Raja, V.; Chanthini, K.M.-P.;

Ramasubramanian, R.; Ramkumar, G.; Ponsankar, A.; Narayanan, K.R.; Vasantha-Srinivasan, P.; et al. Efficacy of Precocene I from Desmosstachya bipinnata as an Effective Bioactive Molecules against the Spodoptera litura Fab. and Its Impact on Eisenia fetida Savigny. Molecules 2021, 26, 6384. https://doi.org/10.3390/molecules262163

Academic Editor: Natalizia Micel

Received: 30 July 2021

Accepted: 12 October 2021

Published: 22 October 202

Publisher's Note: MDPI stays neutral with regard to jurisdictional claims in published maps and institutional affiliations.

Copyright: (c) 2021 by the authors. Licensee MDPI, Basel, Switzerland. This article is an open access article distributed under the terms and conditions of the Creative Commons Attribution (CC BY) license (https:// creativecommons.org/licenses/by/ $4.0 /)$.
3 Department of Zoology, Sri Paramakalyani College, Alwarkurichi 627 412, India; kraman.narayanan@gmail.com

4 Department of Biotechnology, St. Peter's Institute of Higher Education and Research, Avadi 600 054, India; vasanth.bmg@gmail.com

5 Department of Botany and Microbiology, College of Science, King Saud University, Riyadh 11451, Saudi Arabia; jsalkahatani@gmail.com (J.A.); wamona015@gmail.com (M.S.A.)

6 USDA-ARS, Agricultural Research Service, U.S. Horticultural Research Laboratory, 2001 South Rock Road, Fort Pierce, FL 34945, USA; wayne.hunter@usda.gov

7 Department of Entomology and Plant Pathology, Faculty of Agriculture, Chiang Mai University, Chiang Mai 50200, Thailand; patcharink26@gmail.com

8 Innovative Agriculture Research Center, Faculty of Agriculture, Chiang Mai University, Chiang Mai 50200, Thailand

9 Department of Plant Protection, Faculty of Agriculture Saba Basha, Alexandria University, Alexandria 21531,Egypt; rady.shawer@alexu.edu.eg

10 Department of Zoology, Faculty of Science, Derna University, Derna 417230, Libya; moly2gm@gmail.com

* Correspondence: senthil@msuniv.ac.in (S.S.-N.); Ahmedabdelfattah@alexu.edu.eg (A.A.-M.) 
bioactive compound support further research to develop production from the grass D. bipinnata as an affordable resource for Precocene-I-based insecticides.

Keywords: armyworm; botanicals insecticides; phytochemical; toxicity; Noctuidae; histology

\section{Introduction}

Agricultural productivity is drastically reduced due to insect pests, with an estimated annual post-harvest loss of about $10-30 \%$ of major agricultural crops [1]. Climatic conditions in a tropical country such as India favor the growth of agriculture pests, which in turn affect the productivity [2]. Growing economic and environmental concerns have increased interest in the use and development of less persistent, botanical-based insect pest management products. The unselective usage of chemical pesticides results in the development of pests with genetic resistance to insecticides [3], while posing potential hazards with toxic residues, environmental health hazards and a negative impact on beneficial insects, such as predators, parasitoids and pollinators [3]. Phytochemicals in plants offer a huge, untapped variety of chemicals that have potential use to defend crops against agricultural pests [4]. Some botanicals have displayed significant targeted activity against different pests [5]. Common effects on insects from crude extracts or semi-purified isolated fractions of phytochemicals report disruption of development, inhibition of growth by altering expression of the growth regulating hormones or digestive enzymes. Phytochemicals may also produce tissue malformations, adult sterility or increased mortality usually in a dose-dependent manner [6]. Plant phytochemical researchers have identified around 10,000 secondary metabolites [7]. Planning programs for establishing an effective botanical pesticide economy suggest several basic principles: (1) for sustained production, the chosen plants should grow year round, (2) plants must provide significant biomass to yield suitable concentrations of the extracted active compounds and (3) the proper extraction methods for producing a final product that is economically feasible and stable in the final product composition [7]. Indicators of plants that contain potential suitable phytochemistry are identified by being unpalatable, bitter or caustic. Common chemicals from plant with these traits include alkaloids, flavanoids, phenols, quinone, terpenes and coumarin-like compounds, all of which have also been documented to exhibit some level of activity against agricultural pests $[3,6]$.

The destructive feeding behavior of phytophagous larvae in the orders Lepidoptera and Coleoptera is well documented to cause excessive damage to agricultural crops [8-10]. Continuous developments of insecticides or antifeedants such as silicon for pest management are greatly needed. Some of the most significant advances are coming from studies on the effects from secondary plant metabolites [11].

The lepidopteran, Spodoptera litura, commonly called Oriental armyworm, tobacco cutworm, cotton leafworm or taro caterpillar [12], is a member of the devastating "Armyworms" [13]. Polyphagous in nature, these lepidopteran pests are cosmopolitan in distribution [14], with S. litura found predominantly in tropical countries [15]. The larvae are avid feeders with over 150 host species [16]. They extensively infest more than 112 species of crop plants in India [17]. While not a seasonal pest, there may be 7 to 8 generations per year [18] and 12 generations in central India [19]. They infest crops, viz., cotton, groundnut, chilly, tobacco, caster and pulses in India, China and Japan and occur in Australia and New Zealand [20]. The larvae damage seedlings of many crop plants, resulting in severe economic loss [21,22]. The global annual economic loss from this pest has been over USD 2 billion of which $80 \%$ of the loss occurs in India alone [23]. High loss of yield has been directly related to high density levels of S. litura [24] resulting in high levels of defoliation and plant death [25]. Development of insecticide resistance, i.e., an increase of 2700 -fold against pyrethroids [26-28], has resulted in inadequate control of these lepidopteran pests [5]. New solutions are desperately needed against these pests. 
Desmostachya bipinnata L. is a perennial grass, in the taxonomic family Poaceae. The phytochemical constituents of this plant $[29,30]$ and pharmacological uses are well studied [31]. Plant seed extracts have an effective microbiocide. [32,33], though the role of this plant as an insecticide has not received much study, particularly on the lepidopteran insect pest, S. litura. In terrestrial ecosystems, earthworms are important soil fauna that improves the soil matrix and physical properties by decomposing organic materials [34]. Earthworms are used as the index of soil quality; thus, they serve as candidates to study the acute and chronic toxicity of chemical treatments in agricultural settings [35,36]. Toxicological effects of chemicals on various aspects of earthworm such as growth and survival rate, reproductive efficiency, apoptosis nature of cell, membrane stability of lysosome, concentration of metallothionein, activity of enzyme and immune system and DNA damage have been conceded out [37-39].

Application of chemical pesticides not only kills the insect pest but may also affect many non-target organisms [40]. Thus, the earthworm, Eisenia fetida was chosen as the non-target organism in this study, were easily availability, with established protocols for rearing, and toxicity bioassays [41]. The present research reports the effects of Precocene I treatments on leaves fed to S. litura on survival, fecundity, egg hatch, gut histological and development, while also evaluating toxicity on a non-target organism, an earthworm.

\section{Materials and Methods}

\subsection{Chemicals}

The solvents (hexane, chloroform, ethyl acetate, toluene, formic acid and methanol) used in this experiment were bought from Merck (Darmstadt, Germany), and all the solvents used were of HPLC grade. The standard compound Precocene I ( $\geq 95 \%$ purity), synonym: 7-Methoxy-2,2-dimethyl-3-chromene, Empirical Formula (Hill Notation) $\mathrm{C}_{12} \mathrm{H}_{14} \mathrm{O}_{2}$ was obtained from Sigma Aldrich, Mumbai, India.

\subsection{Plant Sample Collection}

The plants Desmostachya bipinnata were collected at the river banks of Kadana Dam at Sivasailam (latitude, $8^{\circ} 39^{\prime} 57.01^{\prime \prime} \mathrm{N}$; longitude, $77^{\circ} 35^{\prime} 18.23^{\prime \prime}$ E; elevation, $62 \mathrm{~m}$ ), Tamil Nadu, India. The collected plants were confirmed with regional flora (Gamble, 1934), and then, voucher specimens were submitted to the SPKCES, Manonmaniam Sundaranar University, Tirunelveli, India.

\subsection{Crude Extract Preparation}

The leaves of Desmostachya bipinnata were shade-dried at room temperature. The dried leaves were powdered and sequentially extracted following the method of Ponsankar et al. [40] with slight modifications. They were extracted serially by using methanol, chloroform and petroleum ether. The solvents in desiccators were removed, and the residues were stored under $4{ }^{\circ} \mathrm{C}$ for further analysis.

\subsection{Isolation of Bioactive Compound}

The crude chloroform extract $(50 \mathrm{~g}$ ) was dissolved in $100 \mathrm{~mL}$ of $90 \%$ ethanol, and aqueous extracts were made from this by adding $200 \mathrm{~mL}$ of distilled water. The fractionation of aqueous extract was performed with column chromatogram with silica gel (60-120 pore size). The elution of column was performed with step gradient mixture of ethyl acetate and ethanol. The collected eluates were fraction I (ethyl acetate), fraction II (ethyl acetate/ethanol, 11:1, v/v), fraction III (ethyl acetate/ethanol, 10:2, v/v), fraction IV (ethyl acetate/ethanol, 9:3, v/v), fraction V (ethyl acetate/ethanol, 8:4, v/v), fraction VI (ethyl acetate/ethanol, 7:5,v/v), fraction VII (ethyl acetate/ethanol, 6:6, v/v), fraction VIII (ethyl acetate/ethanol, 5:7, v/v), fraction IX (ethyl acetate/ethanol, 4:8, v/v), fraction $X$ (ethyl acetate/ethanol, 3:9,v/v), fraction XI (ethyl acetate/ethanol, 2:10, v/v) and fraction XII (10\% ethanol). Further, twelve fractions were evaporated at room temperature for complete dryness. 
The eluted fractions were applied on TLC (60 F254 Merck, Germany) containing formic acid, water, ethyl acetate and toluene (ratio $(v / v)$ of 3:3:25:50), and eluted samples were compared with the standard Precocene I. The TLC plates were squirted with stannous chloride in dilute $\mathrm{HCl}$ of $100 \mathrm{~g} / \mathrm{L}$ and for 1 min heated at $100{ }^{\circ} \mathrm{C}$. The spots obtained were visualized under UV light at $365 \mathrm{~nm}$ and compared with the standard Precocene 1 for the identification of the structure. Fraction VII showed a similar Rf value with that of the standard, Precocene I, and the partly purified fraction VII was recrystallized using methanol to yield the extracted pure compound of D. bipinnata, Db- Precocene I. The eluted VII fraction was analyzed using HPLC studies followed the method of Ponsankar et al. [42]. The characterization of the compound structure was carried out by FT-IR and NMR spectral analyses.

\subsection{Fourier Transform Infrared Spectroscopy Analysis}

The Fourier transform infrared spectroscopy (FT-IR) spectra of fraction VII were observed on Perkin Elmer Spectrum one equipped with an ATR-FTIR unit. A small quantity of the fraction VII was kept in the ATR head, and the recording of spectra carried out at wavelengths from 450 to $4000 \mathrm{~cm}^{-1}$. The spectra resolution was found at $4 \mathrm{~cm}^{-1}$, and sixteen scans were ensued and averaged. Separate software used for analyzing the data observed in the spectrum (Perkin Elmer, Vadodara, India).

\subsection{NMR Analysis}

Fraction VII was subjected to characterization through NMR spectral analysis [42]. The NMR spectra ${ }^{1} \mathrm{H}$ and ${ }^{13} \mathrm{C}$ of the isolated compounds were recorded at $300 \mathrm{mHz}\left({ }^{1} \mathrm{H}\right.$ $\mathrm{NMR}$ ) and $75 \mathrm{mHz}\left({ }^{13} \mathrm{C} \mathrm{NMR}\right)$ employing Bruker (Advance) NMR instrument in $\mathrm{CDCl}_{3}$ solvent with 5-10 drops of dimethyl sulfoxide (1 drop 200 mL). The chemical shifts were referenced to tetra methyl silane and expressed in parts per million.

\subsection{Insect Culture}

The collected S. litura pupae were cultured in the laboratory, Biopesticide and Environmental Toxicology. The emerged adults were transferred to the sterile elastic container containing leaves harvested from castor plant for oviposition and were nursed with $8 \%$ of honey solution dipped in the cotton wool and placed inside the small cap of glass. The laid eggs were retained for hatching in sanitized plastic containers and placed in the ecologically controlled chamber. The required temperature and relative humidity (RH) were maintained in the chamber as $25-27^{\circ} \mathrm{C}$, at $60-70 \%$, respectively. The day/night time was fixed to $13: 11 \mathrm{~h}[27,41]$.

\subsection{Mortality Bioassay}

Mortality bioassay was carried out on II, III and IV instars larvae of S. litura using discriminate dosages $(5,10,15$ and $50 \mathrm{ppm}$ ) of fraction VII (suspended in $0.1 \%$ chloroform). Leaves of castor were provided with set concentrations of fraction VII and air dry for five minutes. For control, chloroform of $0.1 \%$ was sprayed on the castor leaves. The 4-hour starved II, III and IV instar larvae were fed with the fraction-VII-treated leaves $(5,10$, 15 and $50 \mathrm{ppm})$, and the experiments were carried out in a sterilized room $\left(27 \pm 2{ }^{\circ} \mathrm{C}\right)$ with a relative humidity $(\mathrm{RH})$ of $80 \%$. Ten larvae were taken for each concentration. The procedure was passed out with five replicates, and one control group was maintained.

$$
\begin{aligned}
& \text { Corrected percentage of mortality }=\left(1-\frac{\mathrm{n} \text { in } T \text { after treatment }}{\mathrm{n} \text { in } \mathrm{C} \text { after treatment }}\right) \times 100 \\
& \text { Precentage Mortality }(\%)=\frac{\text { Number of larvae dead }}{\text { total number of larvae introduced }} \times 100
\end{aligned}
$$

Mortality rate was recorded at an interval $24 \mathrm{~h}$ and compared with control. The mortality rate of percentage was studied using Equation (1), and corrected percentage 
mortality was carried out by using Abbott's formula [42], Equation (2), where $T$ is the number of larvae in treated groups; $C$ is the number of larvae in control groups.

The corrected data of mortality were exposed to Probit analysis [43] to determine the lethal concentration $\left(\mathrm{LC}_{50}\right.$ and $\left.\mathrm{LC}_{90}\right)$. Developmental aspects were studied using the sub-lethal dosage.

\subsection{Development Studies}

Developmental aspects were studied following the procedure of Senthil-Nathan and Kalaivani and Selin-Rani et al. [21,44]. The second instar emerged larvae were used for biological studies. The starved larvae were placed with castor leaves treated with $6 \mathrm{ppm}$ of fraction VII. Control were provided with $0.1 \%$ chloroform-treated leaves and let dry. Every $24 \mathrm{~h}$, leaves that were not eaten were detached and fresh castor leaves were added. A minimum of ten larvae was maintained for each concentration with five replicates. The treated and control groups were kept in 14L:10D conditions at $28 \pm 2{ }^{\circ} \mathrm{C}$ and $80 \% \mathrm{RH}$. Every $24 \mathrm{~h}$, removal of dead larvae and recording of live individuals were carried out. Fecundity was assessed by noting the emerged moths from the treated larvae. They were further raised with normal adults of the differing sex from the in vitro cultures to observe the progeny number generated, and then, pairs were limited in cover containers with interned castor leaves for oviposition.

\subsection{Antifeedant Activity}

Activity of antifeedant of fraction VII was tested by using the leaf disc choice method [45]. Fraction VII with concentrations of 5, 10, 25 and 50 ppm was used to evaluate their potentiality in view to find the cessation ability on feeding activity against $\mathrm{V}$ instar of S. litura. Leaf discs of $3.5 \mathrm{~cm}$ diameter from castor plant were treated on both sides with $20 \mu \mathrm{L}$ of fraction VII $(5,10,25$ and $50 \mathrm{ppm})$ and, then, air-dried at room temperature. Leaves of control were treated with $0.1 \%$ chloroform. Disc leaf were reserved in petri dish $(15 \mathrm{~cm})$ lined with moistened filter paper. Four-hour-starved V instar were introduced in a petri dish containing control and untreated leaf disc. Five replications were conceded out in each concentration. The treated and control sets were placed in $14 \mathrm{~L}: 10 \mathrm{D}\left(28 \pm 2{ }^{\circ} \mathrm{C}\right.$ and $80 \% \mathrm{RH})$. The Feeding Deterrence Index (FDI) was calculated by employing Formula 3.

$$
F D I=\frac{C-T}{C+T} \times 100
$$

where $C$ and $T$ are the control leaf and treated leaf weights consumed by the $S$. litura [46].

\subsection{Histology Study}

The control and Precocene-I-treated larvae were longitudinally cut through the cuticle and fixed in $4 \%$ formaldehyde for $2 \mathrm{~h}$ at $4{ }^{\circ} \mathrm{C}$ following the method of Raymond et al. [47] and with meagre modification as specified by Pradeepa et al. [48]. The tissue was dehydrated in ascending grades of alcohol, viz., 50, 60, 70, 80, 90 and 100\% for every two hours and put in xylene for $6 \mathrm{~h}$. Then, they were placed in a warm oven and embedded in paraffin to prepare blocks. Sections of about $8 \mathrm{~mm}$ inches were taken and dewaxed by dipping $5 \mathrm{~min}$ in $100 \%$ xylene. The rehydrated tissues in descendant grades of alcohol, viz., 100, 90, 80, 70, 60 and 50\% and, then, with distilled water. They were stained with Ehrlich's hematoxylin and again dehydrated with descending grades of alcohol as mentioned above and counterstained with eosin. The slides were washed once with $100 \%$ alcohol and dipped twice in xylene. Samples were mounted with DPX [49]. Observation on the midgut of control and treated larvae was made by a Nikon microscope (Japan), and the microscope was connected to a computer to the photomicrograph.

\subsection{Earthworm Culture}

Adult earthworms, E. fetida, were reared in the BET laboratory, M.S. University, India, without exposing them to pesticides. A soil mixture and manure of cattle contained wooden 
box E. fetida were introduced and cultured. Distilled water was sprayed in the wooden box to maintain the temperature $\left(28.9 \pm 0.36{ }^{\circ} \mathrm{C}\right)$ and moisture $(30 \%)$. Adult earthworms (350-430 mg) with clitellum were used for experiments [24].

\subsection{Non-Target Acute Toxicity Assay}

The artificial soil was taken for testing [39,44]. The content of the soil was $70 \%$ quartz sand, $20 \%$ clay of Kaolin and $10 \%$ peat sphagnum, and the $\mathrm{pH}$ was maintained at 6.0 by adding calcium carbonate. To $250 \mathrm{mg} / \mathrm{kg}$ of soil, different pesticide concentrations (basis of dry/weight) such as chlorpyrifos, cypermethrin and Db-Precocene I were added. The selected amount of pesticide was mixed into soil in the form of aqueous solution to obtain the working soil.

\subsection{Statistical Analysis}

The statistical analyses of data from larvicidal assay, antifeedant and biological studies were carried out using an ANOVA variance (percentage of square root transformation). The Tukey's family significant error rate by Minitab ${ }^{\circledR} 17$ statistical software (Minitab, Inc., State College, PA, USA) determined the significance between the treatments. If $p \leq 0.05$, then the variance between means was significant (Snedecor and Cochran, 1989). The Probit analysis with accountable interval of $95 \%$ using the Minitab ${ }^{\circledR} 17$ program was accompanied to calculate the lethal concentrations necessary to kill $50 \%$ ( $\mathrm{LC}_{50}$ ) of larvae in $24 \mathrm{~h}$. The Abbott's (1925) equation was utilized to correct the mortality if it was needed.

\section{Results}

\subsection{Identification of Db-Precocene I}

The bioactive compound $\mathrm{Db}$-Precocene I was isolated from chloroform extract of D. bipinnata with the help of chromatographic techniques and was subjected to TLC, FT-IR, HPLC, ${ }^{1} \mathrm{H}$ NMR and ${ }^{13} \mathrm{C}-\mathrm{NMR}$ for compound identification. The TLC profile of $\mathrm{Db}$-Precocene 1 from chloroform extract showed similar retardation factor $(R f)$ value $(R f=0.682)$ when compared with the standard Precocene I.

\subsection{Mortality Bioassay}

The larval mortality was found to be pronounced in second, third and fourth instars of S. litura when they were exposed to the isolated Db-Precocene I (Figure 1A). The II, III and IV instars of $S$. litura showed higher mortality at $60 \mathrm{ppm}$ concentration of Db-Precocene 1 than at 5, 10 and $25 \mathrm{ppm}$. The mortality rate increased with prominent treated dosage (5 ppm, $10 \mathrm{ppm}, 25 \mathrm{ppm}, 60 \mathrm{ppm}$ ) producing a dose-dependent mortality rate.

The $\mathrm{LC}_{50}$ value of $\mathrm{Db}$-Precocene I against the third instar larvae was calculated to be $23.2 \mathrm{ppm}$ (Figure 1B) the Db-Precocene I was tested against the S. litura for toxicity; at $60 \mathrm{ppm}$, the concentration produced a significant mortality of $98 \%\left(F_{4,21}=49.73, p<0.001\right)$, $87 \%\left(F_{4,21}=55.18, p<0.001\right)$ and $81 \%\left(F_{4,21}=52.21, p<0.001\right)$ in the second, third and fourth treated larvae. While it was $80 \%, 62 \%$ and $56 \%$, respectively, at the concentration of $25 \mathrm{ppm}$. Whereas, in $10 \mathrm{ppm}, 48 \%, 38 \%$ and $29 \%$ of mortality was recorded in second, third and fourth instars. Even at the concentration of $5 \mathrm{ppm}$ of Db-Precocene I, significant mortality was observed greater than the control $(p<0.05)$. 

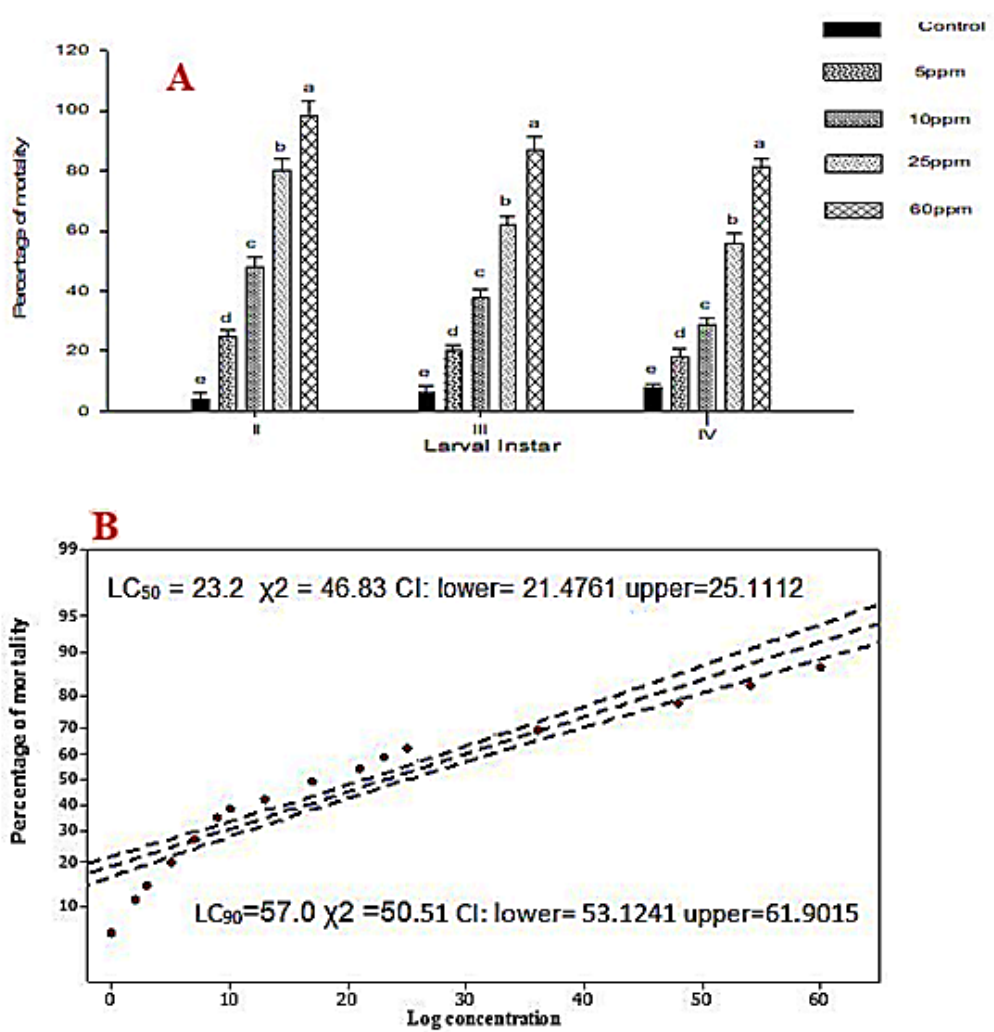

Figure 1. (A) Percent larval mortality was found to be pronounced in second, third and fourth instars of $S$. litura. Means ( $\pm(\mathrm{SE})$ standard error) followed by the same letters above bars indicate no significant difference $(p<0.05)$ according to Tukey's test. $(\mathbf{B})$. Median lethal concentrations $\left(\mathrm{LC}_{50}\right.$ and $\mathrm{LC}_{90}$ ) of Db-Precocene I against fourth instar of S. litura Probit analyses.

\subsection{Development Studies of S. litura}

Survival was significantly decreased with increasing concentrations of Db-Precocene I (at 6 and $8 \mathrm{ppm}$ ). At the concentration of 6 and $8 \mathrm{ppm}$, no survival of larvae was observed on the 19th and 16th day, respectively. Over $90 \%$ mortality was observed at 20 days post treatment at 2 and $4 \mathrm{ppm}$ treatments (Figure 2). The fecundity rate of female S. litura decreased with increasing sub-lethal concentration $(2,4,6$ and $8 \mathrm{ppm})$ of Db-Precocene I compared to control (Figure 3A). At the sub-lethal concentrations $(2,4$ and $6 \mathrm{ppm})$, emergence from pupation decreased to $61 \%\left(F_{3,16}=41.01, p<0.019\right), 54 \%\left(F_{3,16}=41.01\right.$, $p<0.020)$ and $41 \%\left(F_{3,16}=41.01, p<0.015\right)$, whereas in control, the pupal percentage was $78 \%\left(F_{3,16}=41.01, p<0.001\right)$. The greatest rate of reduction in pupation was at $8 \mathrm{ppm}$ of Db-Precocene I, $32 \%\left(F_{3,16}=41.01, p<0.012\right)$.

A substantial reduction in the fecundity of $S$. litura adults occurred at $8 \mathrm{ppm}$ of $\mathrm{Db}-$ Precocene I (228 eggs) $\left(F_{3,16}=48.01, p<0.001\right)$ compared to control $(1040$ eggs $)\left(F_{3,16}=48.01\right.$, $p<0.003)$. At sub-lethal concentrations, smaller reductions in fecundity occurred: at $2 \mathrm{ppm}$ (935 eggs); 4 ppm (743 eggs); at 6 ppm (412 eggs) compared to control (1040 eggs).

A gradual decline in hatchability of S. litura egg correlated with increasing sub-lethal concentration (2-8 ppm) of Db-Precocene I. The greatest hatchability $29 \%$ occurred at the highest sub-lethal concentration compared to control $85 \%\left(F_{3,16}=49.17, p=0.001\right)$. Hatchability was $64 \%, 50 \%$ and $37 \%$ for treatments of $(2,4$ and $6 \mathrm{ppm})$ of Db-Precocene I. 


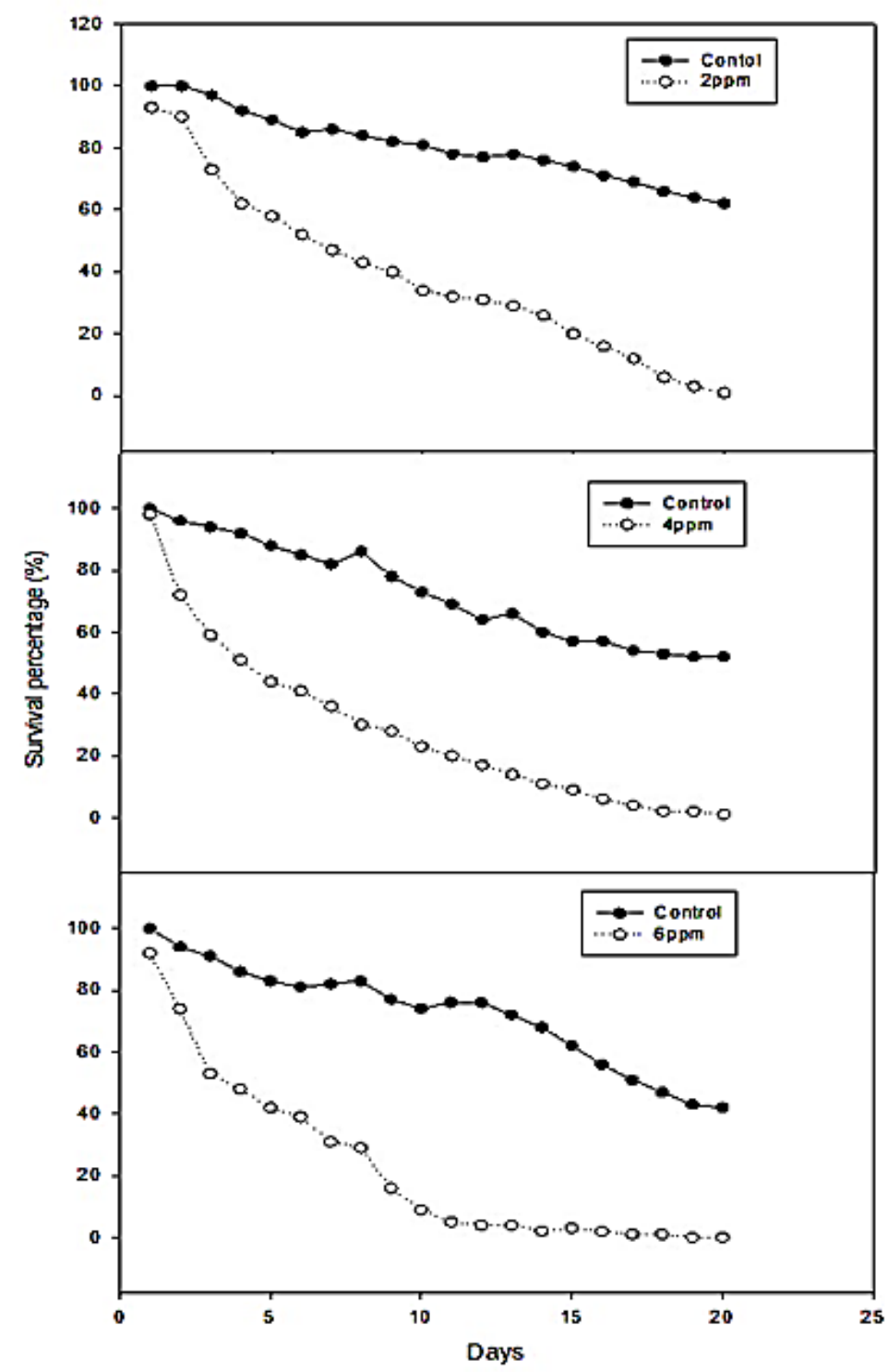

Figure 2. Mean percentage larvae mortality at 20 days after treatment. S. litura fed on leaves with 2, 4 and 6 ppm of Db-Precocene I.
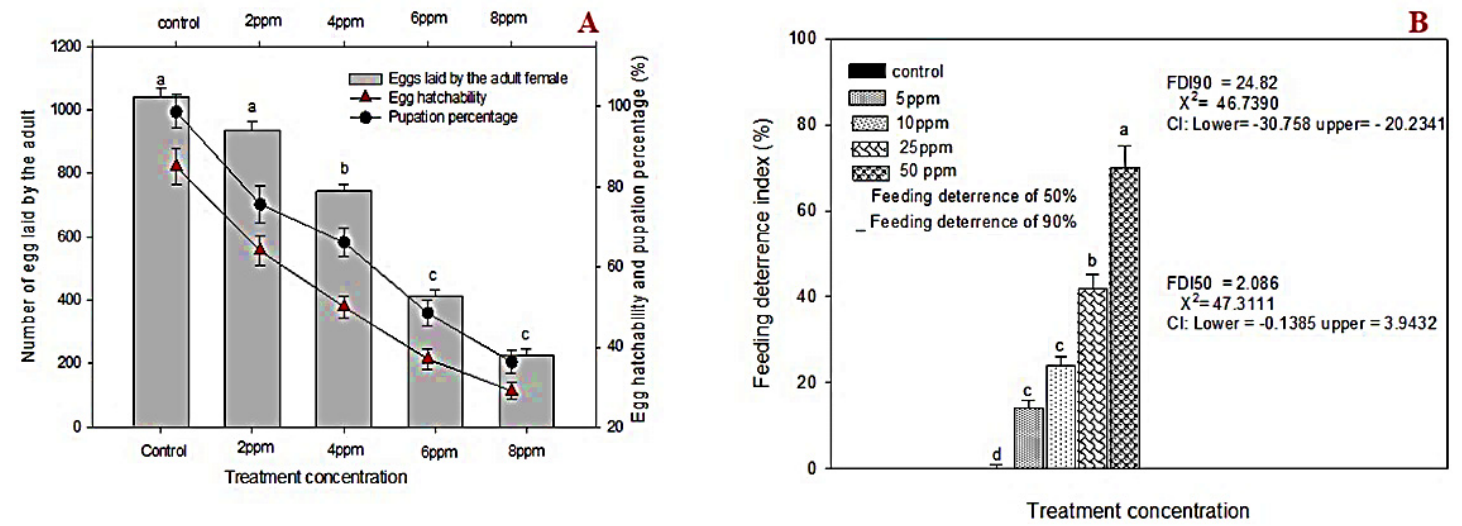

Figure 3. (A) Mean percent fecundity, egg hatch and pupation of S. litura after fed on leaves treated with fraction VII from Desmostachya bipinnata. Means $( \pm$ (SE) standard error) followed by the same letters above bars indicate no significant difference $(p \leq 0.05)$ according to Tukey's test. (B) Antifeedant activity of S. litura after treated with fraction VII from D. bipinnata. Means ( \pm (SE) standard error) followed by the same letters above bars indicate no significant difference $(p \leq 0.05)$ according to Tukey's test. 


\subsection{Antifeedant Activity}

Feeding activity completely ceased at $50 \mathrm{ppm}$ of Db-Precocene-I-treated castor leaves in fifth instar larvae of $S$. litura. The feeding activity was contrariwise to increasing concentration $\mathrm{Db}$-Precocene I. The control feeding deterrence index was $0 \%$, while the concentration of 5, 10, 25 and $50 \mathrm{ppm}$ of Db-Precocene I produced percentages of feeding deterrence of $14\left(F_{4,21}=49.72, p=0.001\right), 24\left(F_{4,21}=49.72, p=0.003\right), 42\left(F_{4,21}=49.72\right.$, $p=0.004)$ and $70\left(F_{4,21}=49.72, p=0.011\right)$, respectively (Figure $3 \mathrm{~B}$ ).

\subsection{Earthworm Toxicity}

Regarding earthworm toxicity, there was no distinct contact toxicity observed after treatment with Db-Precocene I at 50 and $100 \mathrm{ppm}$ using the filter paper test $\left(F_{4,21}=25.17\right.$, $p<0.001)$ with no significance compared to control $\left(F_{4,21}=25.17, p<0.001\right)$. The percentage mortality of earthworm due to contact toxicity with Db-Precocene I at concentrations of 50 and $100 \mathrm{ppm}$ after an exposure period of $24 \mathrm{~h}$ was 7 and $9 \%$, and 12 and $16 \%$ after $48 \mathrm{~h}$ of exposure. Whereas, the chemical pesticides cypermethrin $(10 \mathrm{ppm})$ and monocrotophos (10 ppm) exhibited a visible toxic effect at 24 and $48 \mathrm{~h}$ of exposure of 65 and $78 \%$ and 71 and $86 \%$, respectively. Among the chemical pesticides, monocrotophos caused a more severe effect on the earthworms than cypermethrin (Figure 4).

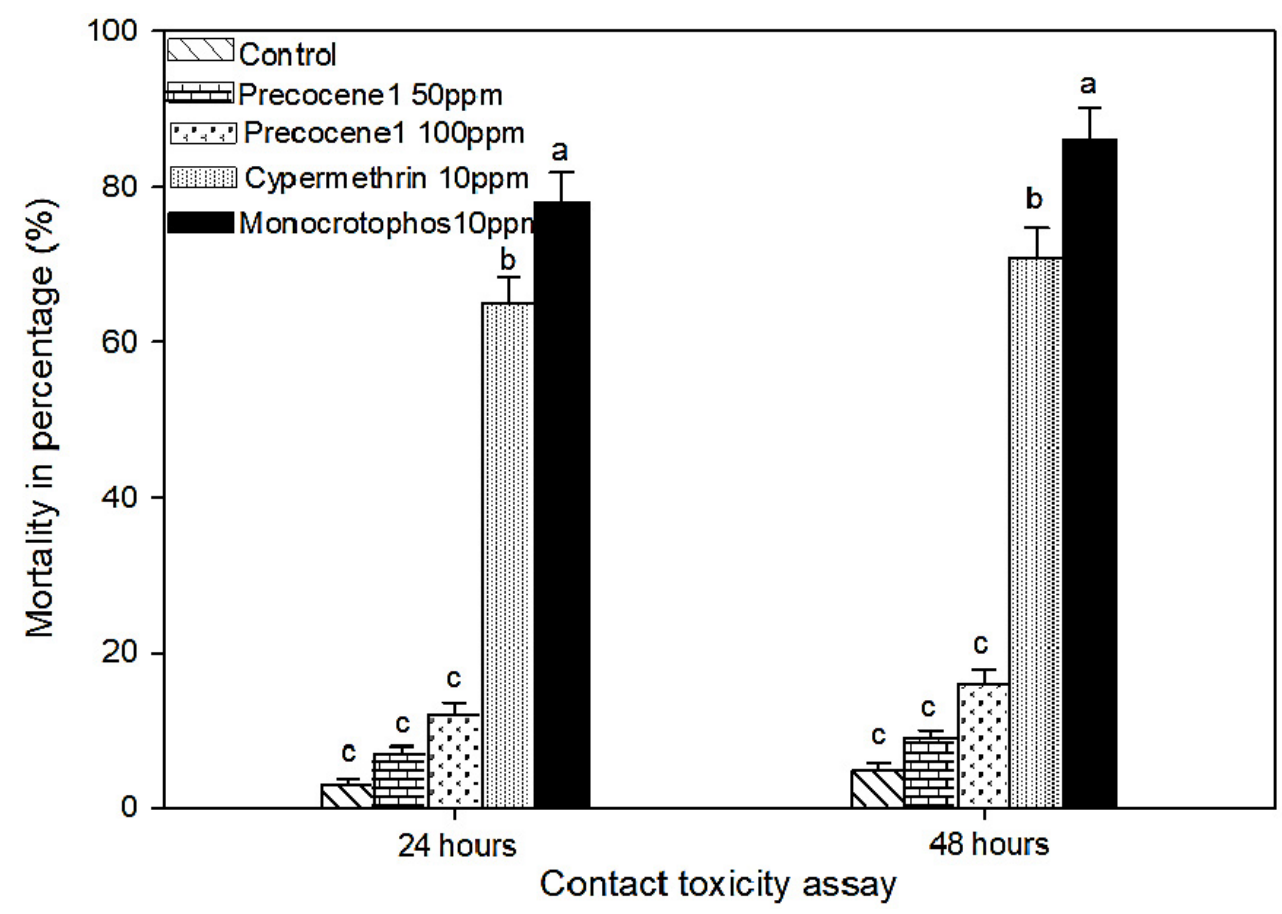

Figure 4. Percentage mortality of earthworm in filter paper test after treated with fraction VII and chemical pesticides. Means ( \pm (SE) standard error) followed by the same letters above bars indicate no significant difference $(p \leq 0.05)$ according to Tukey's test.

\subsection{Histology}

The histology of midgut of S. litura maintained as control exhibited well distinct epithelial cells, columnar cells and conserved epithelial layer; whereas, morphological and cellular variations were observed in the midgut tissue of $S$. litura after being treated with $6 \mathrm{ppm}$ of Db-Precocene I. The major changes due to Db-Precocene I included an alteration in the arrangement of the epithelial layer, enlargement and distortion of epithelial cells and formation of microvilli from the apical membrane with damage in the peritrophic membrane. Further brush border membrane and gut lumen were very much affected when compared to control (Figure 5). 

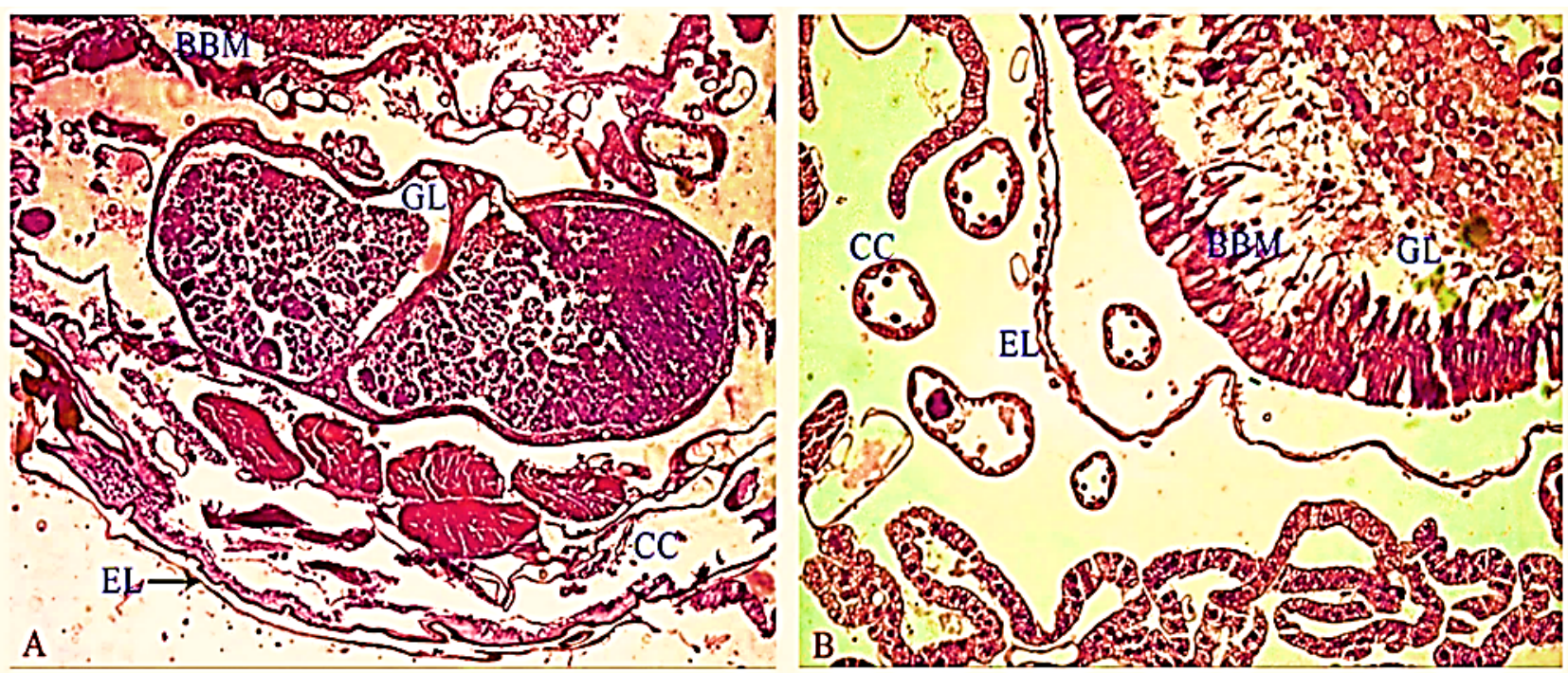

Figure 5. Histological section of the midgut region of fourth instar larvae of S. litura (A) control (CC-columnar cells; EL-epithelial layer; BBM-brush border membrane; GL—gut lumen). (B) Treated concentration of 6ppm of Db-Precocene I (CC—columnar cells; EL—epithelial layer; BBM—brush border membrane; GL—gut lumen).

\subsection{FT-IR}

The results showed the occurrences of various functional groups of Db-Precocene I extracted from D. bipinnata shown in (Figure 6A). When the extract was subjected to FT-IR, the functional group was separated, resulting in the form of peaks. The result confirmed the existence of a specific band at $2971.73 \mathrm{~cm}^{-1}$, showing the $\mathrm{C}-\mathrm{H}$ stretching of $-\mathrm{C}-\mathrm{O}-\mathrm{CH}_{3}$, at $1364.73 \mathrm{~cm}^{-1}$, showing $\mathrm{CH}$ deformation $\mathrm{C}\left(\mathrm{CH}_{3}\right)_{2}$ gem dimethyl, and at $1119.32 \mathrm{~cm}^{-1}$, exhibiting the C-O group; also, the presence of the benzene ring was displayed by the peak's ranges from $802.85-454.15 \mathrm{~cm}^{-1}$.
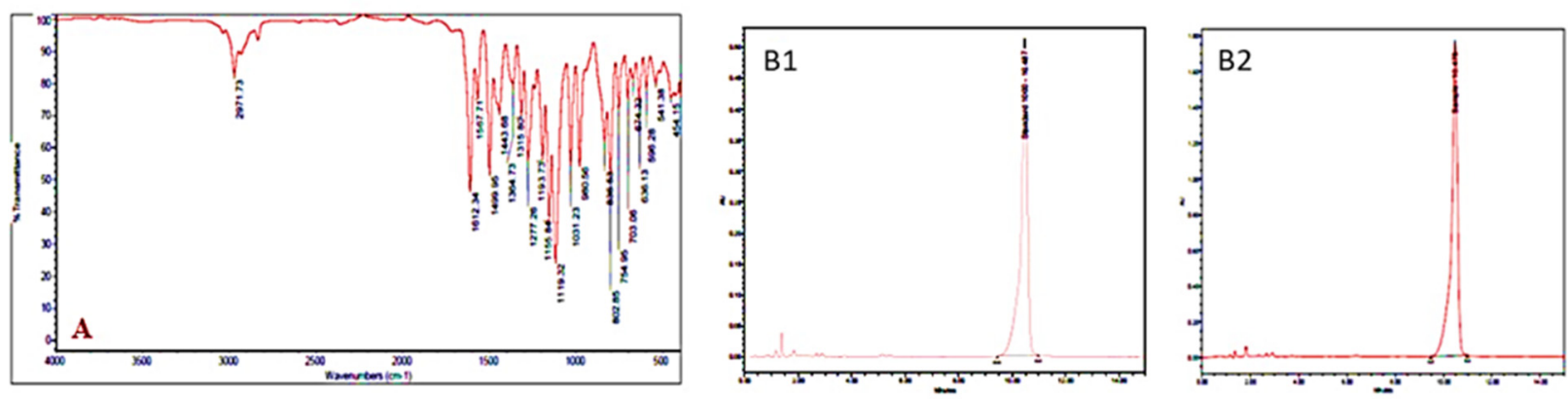

Figure 6. (A). FT-IR spectrum of fraction VII eluted from Desmostachya bipinnata chloroform extract 6. (B1). HPLC analysis of standard compound; (B2) HPLC analysis of fraction VII eluted from Desmostachya bipinnata chloroform extract.

\subsection{HPLC}

The active fraction of $D$. bipinnata was diluted in HPLC-grade chloroform, and the sample was analyzed by injection into the HPLC. The peak obtained was comparable with standard Precocene 1 (Figure 6B). The retention time of the peak for the Db-precocene I sample (10.475) matched with the peak range of value of the Precocene I standard (10.487). The analytical result identified the compound from the chloroform extract fraction VII from D. bipinnata as Precocene I. To substantiate the HPLC result, a confirmation study witH-NMR technique was conducted. 


\subsection{NMR}

The pure compound obtained from the chloroform extract of $D$. bipinnata was subjected to ${ }^{1} \mathrm{H}-\mathrm{NMR}$ and ${ }^{13} \mathrm{C}-\mathrm{NMR}$ and spectra analyses. The values of chemical shifts were presented in $\measuredangle$ scale, and the results were reported in (Figure 7A).
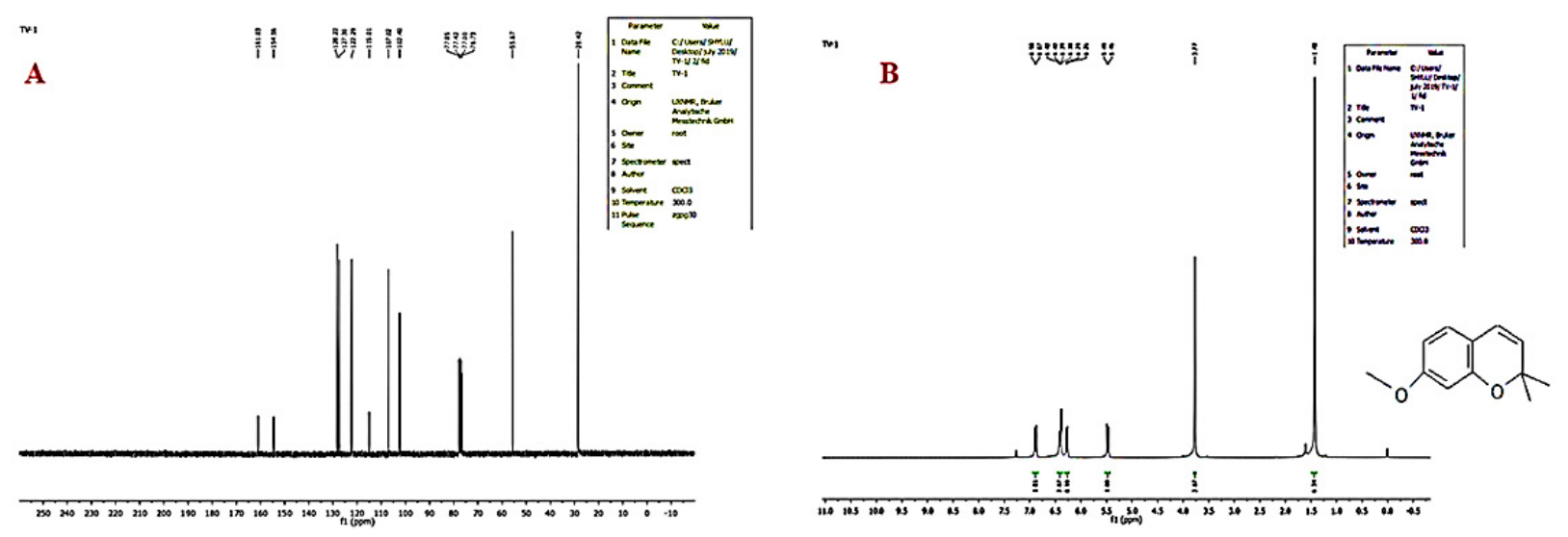

Figure 7. (A). ${ }^{13} \mathrm{C}-\mathrm{NMR}$ spectrum of fraction VII (Db-Precocene I), (B) ${ }^{1} \mathrm{H}-\mathrm{NMR}$ spectrum of fraction VII (Db-Precocene I).

${ }^{1} \mathrm{H}-\mathrm{NMR}\left(\mathrm{CDCL}_{3} \mathrm{MH}_{\mathrm{z}}\right) 8 \mathrm{ppm}$ : $1.43 \mathrm{ppm}$ contained a singlet six proton-two methyl groups at position 2, $3.77 \mathrm{ppm}$ a singlet three proton-one $\mathrm{OCH}_{3}$ group at position 7 , $5.46 \mathrm{ppm}$ a doublet $(J=3 \mathrm{~Hz})$ one proton at position 4, and also, $6.26 \mathrm{ppm}$ exhibited multiplet three protons at positions 5, 6 and 8 (Figure 7B).

\section{Discussion}

The search for eco-friendly botanical chemical alternatives has thrown a light on the unexplored wealth of plants of local origin $[50,51]$. The development of biopesticide products is an international concern focusing on eco-awareness and the inclusion of integrated pest management tactics [52]. As biopesticides are developed, the foundational thought should include (1) a standardized set of criteria for acceptable validation methods; (2) production outlines on how to obtain effective biopesticide products with low cost. This is indispensable to pest management for farmers that cannot rely solely on expensive synthetic pesticides, and (3) the products and production need to provide increased benefits to the farmers and community $[5,53]$. The untapped development of secondary plant metabolites provides a continuous rich resource to develop effective pest management products, such as biorational insecticides across many pests [53,54].

Intensive investigation with plant-derived extracts and phytochemicals have been performed for the past 30 years. In order to develop new treatments that can alleviate insecticide resistance, and to maintain pest management, the path forward depends upon standardized screening, evaluations of efficacy and safety, with the inclusion of economic benefits during production and use by farmers [55].

The agrochemicals of plants that can act as an antifeedant effectively affects the gustatory sensilla, tarsi sensilla [56] and/or odorant receptors of insects. Blocking or disruption of these host selection cues completely changes the behavior of feeding insects and results in reduced consumption, retarded growth and development and, in some circumstances, leads to death [5]. The sensilla gustatory of insects have receptors for positive and negative stimulants. The physiological mode of action on the gustatory receptors can block or prevent insects determining host acceptability information [57,58]. Many researchers are focused on the discovery and use of phytochemicals as bioactive compounds that are suitable for effective pest suppression or repellency that can be developed into insecticides [59].

For example, Yooboon et al. [60] reported on plant-based extracts with the potential for controlling S. litura. The ethanolic extract of Acorus calamus (Linn.) and Piper retrofractum (Linn.) were evaluated for their antifeedant and growth inhibition of S. litura. The study 
also reported the induction of behavioral changes in feeding by larval S. litura, resulting in longer pupation times, after feeding on leaves treated with Precocene I from D. bipinnata. The results were similar to those reported by Lakshmanan et al. [61].

The high mortality rate of S.-litura-larvae-fed Db-Precocene I leaves in our study reflect the potential to be developed into biopesticide to manage the pest $S$. litura. The rate of mortality, the reduced fecundity and egg hatch of S. litura fed on Db-Precocene I leaves corroborates previous reports that evaluated both Precocene I and Precocene II on S. litura [62-65]. While these studies report similar results, the differences observed might be the mode of activity reported for Precocene I in other studies that suggest it inhibits the ovarian DNA synthesis or interferes with vitellogenesis [66].

The structural organization of midgut of S. litura treated as control showed normal histological features but was drastically altered by the treatment of Db-Precocene I. Similar changes were reported when S. litura was treated with other types of plant toxins [44]. For example, treatment with Swetinia mahagoni (Linn.) leaf extracts exhibited major changes in the nature of the epithelial layer in the midgut tissue of S. litura [22].

In the current research, the earthworm did not appear to be affected by the DbPrecocene I treatments at the concentrations tested. The profound mortality observed from the synthetic pesticide treatments demonstrates different modes of activity, and how discovery of novel compounds may produce "environmentally friendlier" insecticides.

\section{Conclusions}

The present investigation shows that the bio-rational derivatives of D. bipinnata and their active metabolites produce toxic effects when fed to the tobacco cutworm, S. litura, at different life stages. Importantly the same concentrations were not shown to produce harmful effects on the natural soil-dwelling earthworm. For further validation of Db-Precocene I bio-activity isolated from the grass, D. bipinnata is needed. The activity on S. litura documented thus far also supports further investigation and analyses as to whether D. bipinnata plants have the economic potential to be a viable production source for Precocene I. If so, then there should be greater interest to move forward with development as a potential treatment to suppress this economically important pest.

Author Contributions: N.S.S. and S.K. designed the research plan and drafted the manuscript. H.S., V.S.-R., K.M.-P.C., R.R. and G.R. performed the experimental works and data compilation. A.P., K.R.N., P.V.-S., J.A., A.G., R.S., A.A.-M. and M.S.A. coordinated the work and discussed the results. W.B.H., S.S.-N., K.P. and A.G revised and formatted the manuscript. All authors have read and agreed to the published version of the manuscript.

Funding: This Research was funded by researcher supporting project number (RSP- 2021/193), King Saud University, Riyadh, Saudi Arabia. In addition, this research work was partially supported by Chiang Mai University, Chiang Mai, Thailand.

Institutional Review Board Statement: Not applicable.

Informed Consent Statement: Not applicable.

Data Availability Statement: The data generated in the current study are available from the corresponding author on request.

Acknowledgments: The authors express their appreciation to the Researchers Supporting Project (RSP-2021/193), King Saud University, Riyadh, Saudi Arabia. Additionally, this research work was partially supported by Chiang Mai University, Thailand.

Conflicts of Interest: The authors declare no conflict of interest.

Sample Availability: Not available. 


\section{References}

1. Ridolfi, C.; Hoffman, V.; Baral, S. Post-Harvest Losses: Global Scale, Solutions, and Relevance to Ghana; International Food Policy Research Institute: Washington, DC, USA, 2018.

2. Srivastava, P.; Singh, R.; Tripathi, S.; Raghubanshi, A.S. An urgent need for sustainable thinking in agriculture-An Indian scenario. Ecol. Indic. 2016, 67, 611-622. [CrossRef]

3. Marchand, P.A. Synthetic agrochemicals: A necessary clarification about their use exposure and impact in crop protection. Environ. Sci. Pollut. Res. 2019, 26, 17996-18000. [CrossRef] [PubMed]

4. Ibanez, S.; Gallet, C.; Després, L. Plant Insecticidal Toxins in Ecological Networks. Toxins 2012, 4, 228-243. [CrossRef] [PubMed]

5. Senthil-Nathan, S. Physiological and biochemical effect of neem and other Meliaceae plants secondary metabolites against Lepidopteran insects. Front. Physiol. 2013, 4, 359. [CrossRef] [PubMed]

6. Senthil-Nathan, S. A Review of Resistance Mechanisms of Synthetic Insecticides and Botanicals, Phytochemicals, and Essential Oils as Alternative Larvicidal Agents Against Mosquitoes. Front. Physiol. 2020, 10, 1591. [CrossRef]

7. Chellappandian, M.; Vasantha-Srinivasan, P.; Senthil-Nathan, S.; Karthi, S.; Thanigaivel, A.; Ponsankar, A. Botanical essential oils and uses as mosquitocides and repellents against dengue. Environ. Internat. 2018, 113, 214-230. [CrossRef]

8. Exley, C.; Guerriero, G. A reappraisal of biological silicification in plants? New Phytol. 2019, 223, 511-513. [CrossRef]

9. Vonzun, S.; Messmer, M.M.; Boller, T.; Shrivas, Y.; Patil, S.S.; Riar, A. Extent of Bollworm and Sucking Pest Damage on Modern and Traditional Cotton Species and Potential for Breeding in Organic Cotton. Sustainability 2019, 11, 6353. [CrossRef]

10. Senthil-Nathan, S.; Kalaivani, K. Efficacy of nucleopolyhedrovirus (NPV) and azadirachtin on Spodoptera litura Fabricius (Lepidoptera: Noctuidae). Biol. Control 2005, 34, 93-98. [CrossRef]

11. Edwin, E.-S.; Vasantha-Srinivasan, P.; Senthil-Nathan, S.; Chellappandian, M.; Karthi, S.; Narayanaswamy, R.; Stanley-Raja, V.; Sivanesh, H.; Ramasubramanian, R.; Al-Huqail, A.A.; et al. Toxicity of Bioactive Molecule Andrographolide against Spodoptera litura Fab and Its Binding Potential with Detoxifying Enzyme Cytochrome P450. Molecules 2021, 26, 5982. [CrossRef]

12. CABI 2019. Datasheet 44520. Spodoptera litura (Taro Caterpillar). Available online: https://www.cabi.org/isc/datasheet/44520 (accessed on 12 October 2019).

13. Nagoshi, R.N.; Ni Htain, N.; Boughton, D.; Zhang, L.; Xiao, Y.; Nagoshi, B.Y.; Mota-Sanchez, D. Southeastern Asia fall armyworms are closely related to populations in Africa and India, consistent with common origin and recent migration. Sci. Rep. 2020, 10, 1421. [CrossRef]

14. Hadapad, A.; Chaudhari, C.S.; Kulye, M.; Chaudele, A.G.; Salunkhe, G.N. Studies on chitin synthesis inhibitors against gram pod borer, Helicoverpa armigera (Hub.). J. Nat. Con. 2001, 13, 137-140.

15. Ulrichs, C.h.; Mewis, I. Seasonal abundance of two armyworm species, Spodoptera exigua (Hübner) and Spodoptera litura (F.) in the Philippines. Commun. Agric. Appl. Biol. Sci. 2004, 69, 323-328.

16. Senthil-Nathan, S. Effects of Melia azedarach on nutritional physiology and enzyme activities of the rice leaffolder Cnaphalocrocis medinalis (Guenée) (Lepidoptera: Pyralidae). Pestic. Biochem. Physiol. 2006, 84, 98-108. [CrossRef]

17. Mallikarjuna, N.; Kranthi, K.R.; Jadhav, D.R.; Kranthi, S.; Chandra, S. Influence of foliar chemical compounds on the development of Spodoptera litura (Fab.) in interspecific derivatives of groundnut. J. Appl. Entomol. 2004, 128, 321-328. [CrossRef]

18. Ateyyat, M.; Abu-Romman, S.; Abu-Darwish, M.; Ghabeish, I. Impact of Flavonoids against Woolly Apple Aphid, Eriosoma lanigerum (Hausmann) and Its Sole Parasitoid, Aphelinus mali (Hald.). J. Agric. Sci. 2012, 4, 227. [CrossRef]

19. Wightman, J.A.; Amin, P.W. Groundnut pests and their control in the semi-arid tropics. Trop. Pest Manag. 1988, 34, 218-226. [CrossRef]

20. Dinesh-Kumar, A.; Srimaan, E.; Chellappandian, M.; Vasantha-Srinivasan, P.; Karthi, S.; Thanigaivel, A.; Ponsankar, A.; Chanthini, K.M.-P.; Shyam-Sundar, N.; Annamalai, M.; et al. Target and non-target response of Swietenia Mahagoni Jacq. chemical constituents against tobacco cutworm Spodoptera litura Fab. and earthworm, Eudrilus eugeniae Kinb. Chemosphere 2018, 199, 35-43. [CrossRef] [PubMed]

21. Senthil-Nathan, S.; Kalaivani, K. Combined effects of azadirachtin and nucleo polyhedrovirus (SpltNPV) on Spodoptera litura Fabricius (Lepidoptera: Noctuidae) larvae. Biol. Control. 2006, 39, 96-104. [CrossRef]

22. Chandrasekaran, R.; Revathi, K.; Nisha, S.; Kirubakaran, S.A.; Sathish-Narayanan, S.; Senthil-Nathan, S. Physiological effect of chitinase purified from Bacillus subtilis against the tobacco cutworm Spodoptera litura Fab. Pestic. Biochem. Physiol. 2012, 104, 65-71. [CrossRef]

23. Grzywacz, D.; Richards, A.; Rabindra, R.J.; Saxena, H.; Rupela, O.P. Efficacy of biopesticides and natural plant products for H. armigera control. In Heliothis/Helicoverpa Management_Emerging Trends and Strategies for Future Research; Sharma, H.C., Ed.; Oxford \& IBH: New Delhi, India, 2005; pp. 371-389.

24. Vasantha-Srinivasan, P.; Senthil-Nathan, S.; Thanigaivel, A.; Edwin, E.-S.; Ponsankar, A.; Selin-Rani, S.; Pradeepa, V.; SakthiBhagavathy, M.; Kalaivani, K.; Hunter, W.B.; et al. Developmental response of Spodoptera litura Fab. to treatments of crude volatile oil from Piper betle L. and evaluation of toxicity to earthworm, Eudrilus eugeniae Kinb. Chemosphere 2016, 155, 336-347. [CrossRef] [PubMed]

25. Wightman, J.A.; Dick, K.M.; Rao, G.V.R.; Shanower, T.C.; Gold, C.G. Pests of groundnut in semi-arid tropics. In Insect Pests of Tropical Food Legumes; Singh, S.R., Ed.; J. Wiley \& Sons: Chichester, UK, 1990; pp. 243-322.

26. Gandhi, K.; Patil, R.H.; Srujana, Y. Field resistance of Spodoptera litura (Fab.) to conventional insecticides in India. Crop Prot. 2016, 88, 103-108. 
27. Karthi, S.; Vaideki, K.; Shivakumar, M.S.; Ponsankar, A.; Thanigaivel, A.; Chellappandian, M.; Vasantha-Srinivasan, P.; Chanthini, K.M.; Hunter, W.B.; Senthil-Nathan, S. Effect of on the mortality of Aspergillus flavus and activity of antioxidant enzymes of Spodoptera litura Fab. (Lepidoptera: Noctuidae) larvae. Pestic. Biochem. Physiol. 2018, 149, 54-60. [CrossRef]

28. Awaad, A.S.; Mohamed, N.H.; Maitland, D.J.; Soliman, G.A. Anti-ulcerogenic activity of extract and some isolated flavonoids from Desmostachia bipinnata (L.) Stapf. Rec. Nat Prod. 2008, 2, 76-82.

29. Ramadan, M.A.; Safwat, N.A. Antihelicobacter activity of aflavonoid compound isolated from Desmostachya bipinnata. Aust. J. Basic Appl. Sci. 2009, 3, 2270-2277.

30. Golla, U.; Bhimathati, S.S.R. Evaluation of Antioxidant and DNA Damage Protection Activity of the Hydroalcoholic Extract ofDesmostachya bipinnataL. Stapf. Sci. World J. 2014, 2014, 215084. [CrossRef]

31. Panda, S.; Choudhury, N.S.K.; Patro, V.J.; Pradhan, D.K.; Jana, G.K. Analgesic, antipyretic and anti-inflammatory effect of the whole plant extract of Desmostachya bipinnata Stapf (Poaceae) in albino rats. Drug Invent. Today 2009, 1, 150-153.

32. Joshi, K.; Mandavia, M.; Golakiya, B. Comparative Study of Phytochemical Analysis, Antimicrobial and Antioxidant Activity of Different Root Extracts of Desmostachya bipinnata Stapf (Kush). Int. J. Curr. Microbiol. Appl. Sci. 2017, 6, 129-137. [CrossRef]

33. Lavelle, P.; Spain, A.V. Soil Ecology; Kluwer: London, UK, 2001.

34. ISO. Soil Quality-Effect of Pollutants on Earthworms (Eisenia fetida): Part 2: Determination of Effect on Reproduction; Guideline DIS11268-2; International Standards Organization: Geneva, Switzerland, 1998.

35. Lin, L.J.; Zhu, X.M.; Shao, J.R.; Jiang, X.J.; Yang, Y.X. Effect of compound pollution of Zinc and chromium on soil enzyme activity at different growth stages of rice plant. J. Nuclear Agric. Sci. 2007, 21, 623-629.

36. Wu, S.; Zhang, H.; Zhao, S.; Wang, J.; Li, H.; Chen, J. Biomarker responses of earthworms (Eisenia fetida) exposured to phenanthrene and pyrene both singly and combined in microcosms. Chemosphere 2012, 87, 285-293. [CrossRef]

37. Sforzini, S.; Boeri, M.; Dagnino, A.; Oliveri, L.; Bolognesi, C.; Viarengo, A. Genotoxicity assessment in Eisenia and reicoelomocytes: A study of the induction of DNA damage and micronuclei in earthworms exposed to B[a]P and TCDD-spiked soils. Mutat. Res. 2012, 746, 35-41. [CrossRef]

38. Reinecke, S.; Reinecke, A. Biomarker response and biomass change of earthworms exposed to chlorpyrifos in microcosms. Ecotoxicol. Environ. Saf. 2007, 66, 92-101. [CrossRef]

39. OECD. Earthworm Acute Toxicity Tests. Chemicals Testing Guideline 207; Organization for Economic Cooperation and Development (OECD) Publications: Paris, France, 1984.

40. Ponsankar, A.; Sahayaraj, K.; Senthil-Nathan, S.; Vasantha-Srinivasan, P.; Karthi, S.; Thanigaivel, A.; Petchidurai, G.; Madasamy, M.; Hunter, W.B. Toxicity and developmental effect of cucurbitacin E from Citrullus colocynthis L. (Cucurbitales: Cucurbitaceae) against Spodoptera litura Fab. and a non-target earthworm Eisenia fetida Savigny. Environ. Sci. Pollut. Res. 2019, 27, 23390-23401. [CrossRef] [PubMed]

41. Rattanapan, A.; Visetson, S.; Milne, J.; Ngernsiri, L.; Sudthongkong, C.; Bullangpoti, V. Molecular detection of gene responsible for expression of detoxification enzyme in Spodoptera litura (F.). In Proceedings of the 7th National Plant Protection, Cheing Mai, Thailand, 27 March 2012.

42. Abbott, W.S. A Method of Computing the Effectiveness of an Insecticide. J. Econ. Entomol. 1925, 18, 265-267. [CrossRef]

43. Finney, D.J. Probit Analysis, 3rd ed.; Cambridge University Press: London, UK, 1971; p. 383.

44. Selin-Rani, S.; Senthil-Nathan, S.; Revathi, K.; Chandrasekaran, R.; Thanigaivel, A.; Vasantha-Srinivasan, P.; Ponsankar, A.; Edwin, E.S.; Pradeepa, V. Toxicity of Alangium salvifolium Wang chemical constituents against the tobacco cutworm Spodoptera litura Fab. Pestic. Biochem. Physiol. 2016, 126, 92-101. [CrossRef]

45. Nathan, S.S.; Sehoon, K. Effects of Melia azedarach L. extract on the teak defoliator Hyblaea puera Cramer (Lepidoptera: Hyblaeidae). Crop. Prot. 2006, 25, 287-291. [CrossRef]

46. Sadek, M.M. Antifeedant and toxic activity of Adhatoda vasica leaf extract against Spodoptera littoralis (Lep., Noctuidae). J. Appl. Entomol. 2003, 127, 396-404. [CrossRef]

47. Raymond, D.N.; Omar, F.; Mady, N.; Abdoulaye, D.; Joseacute, M.A. Toxic effects of neem products (Azadirachta indica A. Juss) on Aedes aegypti Linnaeus 1762 larvae. Afr. J. Biotechnol. 2007, 6, 2846-2854. [CrossRef]

48. Pradeepa, V.; Sathish-Narayanan, S.; Kirubakaran, S.A.; Thanigaivel, A.; Senthil-Nathan, S. Toxicity of aristolochic acids isolated from Aristolochia indica Linn (Aristolochiaceae) against the malarial vector Anopheles stephensi Liston (Diptera: Culicidae). Exp. Parasitol. 2015, 153, 8-16. [CrossRef]

49. Senthil-Nathan, S. A review of bio pesticides and their mode of action against insect pests. In Environmental Sustainability-Role of Green Technologies; Springer-Verlag: Berlin, Germany, 2015; pp. 49-63.

50. Singh, B.; Kaur, T.; Kaur, S.; Manhas, R.K.; Kaur, A. Insecticidal potential of an endophytic Cladosporium velox against Spodoptera litura mediated through inhibition of alpha glycosidases. Pestic. Biochem. Physiol. 2016, 131, 46-52. [CrossRef] [PubMed]

51. Edwin, E.-S.; Vasantha-Srinivasan, P.; Senthil-Nathan, S.; Thanigaivel, A.; Ponsankar, A.; Pradeepa, V.; Selin-Rani, S.; Kalaivani, K.; Hunter, W.B.; Abdel-Megeed, A.; et al. Anti-dengue efficacy of bioactive andrographolide from Andrographis paniculata (Lamiales: Acanthaceae) against the primary dengue vector Aedes aegypti (Diptera: Culicidae). Acta Trop. 2016, 163, 167-178. [CrossRef] [PubMed]

52. Senthil-Nathan, S.; Choi, M.-Y.; Paik, C.-H.; Kalaivani, K. The toxicity and physiological effect of goniothalamin, a styryl-pyrone, on the generalist herbivore, Spodoptera exigua Hübner. Chemosphere 2008, 72, 1393-1400. [CrossRef] [PubMed] 
53. Khan, S.; Taning, C.N.T.; Bonneure, E.; Mangelinckx, S.; Smagghe, G.; Shah, M.M. Insecticidal activity of plant-derived extracts against different economically important pest insects. Phytoparasit 2017, 45, 113-124. [CrossRef]

54. Ayil-Gutiérrez, B.A.; Teyer, L.F.S.; Vazquez-Flota, F.; Monforte-González, M.; Tamayo-Ordóñez, Y.; Tamayo-Ordóñez, M.C.; Rivera, G. Biological effects of natural products against Spodoptera spp. Crop. Prot. 2018, 114, 195-207. [CrossRef]

55. Carvalho, F.P. Pesticides, environment, and food safety. Food Energy Secur. 2017, 6, 48-60. [CrossRef]

56. Seada, M.A.; Ignell, R.; Al Assiuty, A.N.; Anderson, P. Functional Characterization of the Gustatory Sensilla of Tarsi of the Female Polyphagous Moth Spodoptera littoralis. Front. Physiol. 2018, 9, 1606. [CrossRef]

57. Yazdani, E.; Sendi, J.J.; Aliakbar, A.; Senthil-Nathan, S. Effect of Lavandula angustifolia essential oil against lesser mulberry pyralid Glyphodes pyloalis Walker (Lep: Pyralidae) and identification of its major derivatives. Pestic. Biochem. Physiol. 2013, 107, 250-257. [CrossRef]

58. Sollai, G.; Crnjar, R. The contribution of gustatory input to larval acceptance and female oviposition choice of potential host plants in Papilio hospiton (Géné). Arch. Insect Biochem. Physiol. 2019, 100, e21521. [CrossRef]

59. Nathan, S.S.; Kalaivani, K.; Murugan, K.; Chung, P.G. The toxicity and physiological effect of neem limonoids on Cnaphalocrocis medinalis (Guenée) the rice leaffolder. Pestic. Biochem. Physiol. 2005, 81, 113-122. [CrossRef]

60. Yooboon, T.; Pengsook, A.; Ratwatthananon, A.; Pluempanupat, W.; Bullangpoti, V. A plant-based extract mixture for controlling Spodoptera litura (Lepidoptera: Noctuidae). Chem. Biol. Technol. Agric. 2019, 6, 5. [CrossRef]

61. Ponsankar, A.; Vasantha-Srinivasan, P.; Senthil-Nathan, S.; Thanigaivel, A.; Edwin, E.-S.; Selin-Rani, S.; Kalaivani, K.; Hunter, W.B.; Alessandro, R.T.; Abdel-Megeed, A.; et al. Target and non-target toxicity of botanical insecticide derived from Couroupita guianensis L. flower against generalist herbivore, Spodoptera litura Fab. and an earthworm, Eisenia foetida Savigny. Ecotoxicol. Environ. Saf. 2016, 133, 260-270. [CrossRef]

62. Jeyasankar, A.; Raja, N.; Ignacimuthu, S. Antifeedant and growth inhibitory activities of Syzygium lineare against Spodoptera litura (Lep: Noct). Curr. Res. J. Biol. Sci. 2010, 2, 173-177.

63. Kamaraj, C.; Rahuman, A.A.; Bagavan, A. Antifeedant and larvicidal effects of plant extracts against Spodoptera litura (F.), Aedes aegypti L. and Culex quinquefasciatus Say. Parasitol. Res. 2008, 103, 325-331. [CrossRef]

64. Srivastava, S.; Kumar, K. Juvenilizing effects of ethoxy precocene in a lepidopteran insect. Indian J. Exp. Biol. 1999, 37, 379-383.

65. Zhou, F.; Zhu, G.; Zhao, H.; Wang, Z.; Xue, M.; Li, X.; Xu, H.; Ma, X.; Liu, Y. Sterilization Effects of Adult-targeted Baits Containing Insect Growth Regulators on Delia antiqua. Sci. Rep. 2016, 6, 32855. [CrossRef] [PubMed]

66. Tripathi, G.; Kachhwaha, N.; Dabi, I. Comparative studies on carbofuran-induced changes in some cytoplasmic and mitochondrial enzymes and proteins of epigeic, anecic and endogeic earthworms. Pestic. Biochem. Physiol. 2010, 96, 30-35. [CrossRef] 